\title{
University Teachers' Opinions about Higher Education Pedagogical Training Courses in Slovenia
}

KATARINA AšKerC VENIGER ${ }^{1}$

$\approx$ Pedagogical training courses (PTCs) for university teachers have often been discussed and have become a widespread trend in recent years in many countries. Many university teachers consider pedagogical training (PT) as a valuable tool in their teaching practice. In Slovenia, however, there is little evidence of teachers' opinions and beliefs regarding PTCs. ${ }^{2}$ Many authors consider the effect of PTCs in higher education (HE) on teaching questionable, but there is also evidence of the positive impact of PTCs on university teaching. The results of the present survey show that there are statistically significant differences in teachers' opinions on initial and sustained PTCs. Formal education for teaching in primary and/ or secondary schools is often considered as appropriate for teaching in HE. The respondents with higher titles attributed the lowest importance to sustained PTCs. Those involved in (short) PTCs attributed less importance to PT, as well as to the certificate of participation in PT in comparison to the respondents who were not involved in PTCs. On the other hand, the respondents with the highest participation in PT ( 51 hours and more) are more in favour of PTCs, which confirms the preliminary findings that courses of longer duration provide more opportunities to affect teachers' pedagogical thinking and conceptions of teaching and learning in comparison to shorter courses.

Keywords: initial pedagogical training, habilitation procedures, sustained pedagogical training, university teaching

1 Slovenian Centre for Mobility and European Educational and Training Programmes, Slovenia; katarina.askerc.veniger@cmepius.si.

2 In this paper, when talking about PTCs and pedagogical training (PT), courses for higher education teaching staff are meant. 


\section{Mnenja univerzitetnih učiteljev o visokošolskih pedagoških usposabljanjih v Sloveniji}

KatARina AšKerc Veniger

$\approx$ Pedagoška usposabljanja za univerzitetne učitelje so v preteklih letih pogosta tema diskusij in so postala široko razširjen trend $\mathrm{v}$ številnih državah. Veliko univerzitetnih učiteljev pedagoška usposabljanja obravnava kot uporabno orodje v svoji učni praksi, malo pa je dokazov o mnenjih in prepričanjih učiteljev glede pedagoških usposabljanj v Sloveniji. ${ }^{3}$ Številni avtorji učinek pedagoških usposabljanj v visokem šolstvu (VŠ) obravnavajo kot vprašljiv, vendar obstajajo tudi dokazi o pozitivnem učinku pedagoških usposabljanj na univerzitetno poučevanje. Rezultati te raziskave kažejo, da obstajajo statistično značilne razlike v mnenju učiteljev glede začetnih in stalnih pedagoških usposabljanj. Formalna izobrazba za poučevanje na primarni in/ali sekundarni ravni je pogosto obravnavana kot ustrezna za poučevanje v VŠ. Respondenti z višjimi nazivi pripisujejo najnižji pomen stalnim pedagoškim usposabljanjem. Tisti, ki so bili vključeni v (kratka) pedagoška usposabljanja, pripisujejo manj pomembnosti pedagoškim usposabljanjem pa tudi potrdilom o udeležbi v pedagoških usposabljanjih v primerjavi $\mathrm{z}$ respondenti, ki niso bili vključeni v pedagoška usposabljanja. Na drugi strani pa so respondenti z največjo udeležbo v pedagoških usposabljanjih ( 51 ur in več) bolj naklonjeni pedagoškim usposabljanjem, kar potrjuje predhodne ugotovitve, da daljša usposabljanja zagotavljajo več priložnosti za vplivanje na pedagoško mišljenje ter pojmovanje poučevanja in učenja v primerjavi s krajšimi usposabljanji.

Ključne besede: začetna pedagoška usposabljanja, habilitacijski postopki, stalna pedagoška usposabljanja, univerzitetno poučevanje

3 Ko v prispevku omenjamo pedagoška usposabljanja, so mišljena usposabljanja za visokošolsko učno osebje. 


\section{Introduction}

Quality and effective university teaching has received increased attention in recent years, and training of university teachers has become quite a widespread trend in many countries (Postareff, Lindblom-Ylänne \& Nevgi, 2007). Traditionally, however, research carries more weight at universities, while teaching is considered a secondary preoccupation of teaching staff (Leitner, 1998; Pleschová et al., 2012). Consequently, professional development in teaching practice has not been a priority for new university teachers to date (Lisewski, 2006). Quality teaching in $\mathrm{HE}$ is vital for learning, but university teaching staff in Europe are not as well prepared for their teaching career as for research (Pleschová et al., 2012). However, through proper steering, simulation and evaluation of the learning process of students, teaching is becoming increasingly important (Leitner,1998). Fry (2006) writes that, in the last decade of the $20^{\text {th }}$ century, there were two factors (in the UK) that pushed the government towards taking greater interest in teaching quality: increased pressure on resources, and rising student numbers at universities. Perhaps due to the latter, "initial training programmes for university teachers are now widespread in many institutions both in the UK and internationally" (Coffey \& Gibbs, 2000, p. 385).

In Slovenia, too, PTCs for university teachers have become more common in recent years. There is nonetheless little evidence concerning teachers' opinions and beliefs regarding PTCs and their placement in habilitation procedures. The present study attempts to explore PTCs with an emphasis on Slovenian university teachers' opinions and beliefs regarding initial and sustained PT and assessment of the pedagogical qualification of the individual, with regard to which student evaluation of teaching (SET) can be considered as an important source of information. Although, in Slovenia, as in most European countries, teachers are not required to obtain a certificate of teaching competencies in habilitation procedures, this study presents the level of importance that teachers attribute to PTCs, the "probationary lecture" and SET with regard to the process of habilitation.

\section{Background}

Current efforts focus on making PT a standard part of the required qualifications of university teachers (Leitner, 1998). Professional teaching that meets student needs and academic standards has historically been "perhaps regarded as mainly the preserve of the individual" (Fry, 2006, p. 96). Nowadays, training of university teachers is essential for excellent teaching (High Level Group ..., 2013), as, without PT teaching, decisions are based on know-how accumulated 
during the teaching career, and on imitating those with more experience (Rosado Pinto, 2008). If the university seeks to educate better graduates and reduce drop-out rates, it should appropriately encourage teachers to improve their teaching, not just their research (Marentič Požarnik, 1998).

Leitner (1998, p. 342-343) presents Elton's recommendation (1993, p. 69): teachers who have never been taught how to teach must receive some PT, and "if good teachers work with institutions of academic pedagogy[,] they will improve their work. The results will be known and will also influence those who perhaps are not so good". However, if teachers are expected to attend PTCs, courses should be clearly defined (Marentič Požarnik, 1998). Furthermore, pedagogical competencies are subject to evaluation, which necessitates providing opportunities to acquire such competencies (Leitner, 1998). Leitner (ibid.) writes that a university or college should offer an adequate pedagogical qualification and in-service PTCs to each young teacher in order to help fill in the gaps that have been found as a result of an evaluation process. Otherwise, the data obtained through evaluation can be nothing more than "the construction with data of a tower of Babel" (ibid., p. 342). In addition, certificates of participation in PTCs should be recognised as an important element of assessment of pedagogical qualification in the process of habilitation (Marentič Požarnik, 1998).

In Slovenia, attending PTCs still does not confer any benefits, or is allocated minimal points, in the process of habilitation, despite the fact that the Resolution on the National HE Programme 2011-2020 (OG RS, 2011, hereinafter: NHEP) devotes special attention to teaching excellence and teaching. In this regard, HEIs should offer teaching support to teaching staff; they should establish special development centres on HE learning and teaching, which should also provide research on this topic. The NHEP also determines that the Slovenian Quality Assurance Agency (SQAA) should review institutional teaching support from 2012 onwards. In the process of habilitation, however, only one out of four Slovenian universities requires proof of participation in PT. Two Slovenian universities allocate only one point for attending PTCs, which is the lowest maximum number of points achievable in all of the relevant categories within pedagogical activity. The habilitation criteria of the remaining universities do not contain a category for participation in PT. One shared characteristic of the habilitation criteria of Slovenian universities is that the most important evidence of teacher excellence is a "probationary lecture" for new teachers (OG RS, 2010; UL, 2012; UM, 2012; UNG, 2013; UPR, 2014a; UPR, 2014b; UPR 2014C; Aškerc, 2013). However, it is not officially known whether the specially appointed commissions for assessing pedagogical skills have ever rejected a candidate on the basis of not meeting the "criteria" for passing the "probationary lecture". 
Given that a single "probationary lecture" is inadequate for assessing pedagogical skills and insufficient for improving teaching competencies, the impact of PTCs on teaching as a basis for properly assuring the anticipated level of teaching skills will be presented in the continuation.

\section{The impact of PTCs on university teaching}

Although many authors consider the effect of teachers' training in HE on their teaching questionable (Coffey \& Gibbs, 2000; Norton et al., 2005; Postareff, Lindblom-Ylänne \& Nevgi, 2007), there is evidence of the positive impact of PTCs on teaching. Postareff, Lindblom-Ylänne and Nevgi (2007) found that training has positive effects on teachers' approach to teaching and on their teaching methods. Sustained programmes of longer duration (e.g. one year or at least 30 ECTS) ensure more opportunities to affect teachers' pedagogical thinking and conceptions of teaching and learning in comparison to shorter courses, which may cause uncertainty among teachers about their teaching skills. Furthermore, teachers report only positive effects of PT on teaching; it is, however, possible that PTCs are more frequently taken by teachers who are more motivated to improve their teaching (ibid.). Gibbs and Coffey (2004, p. 98) found that teachers became more student-centred and less teacher-centred after a period of 4-18 months of PT, and their teaching skills, as judged by students, improved significantly. In addition, the superficial approach of students declined after their teachers had undergone PTCs. The authors nonetheless state that "we are still not in a position to demonstrate that it was the training that resulted in the positive changes [...]". Norton et al. (2005) found that there was no significant difference in teachers' beliefs and intentions between a group of UK teachers who had taken their institution's programme on teaching and learning, and a group who had no PT. Furthermore, "an effect of training was masked by [the] effect of lack of experience" (ibid., p. 560).

Nevertheless, Postareff, Lindblom-Ylänne and Nevgi (2007) found that PT enhances the shift from an "information transmission/teacher-focused" approach, to a "conceptual change/student-focused" approach. Teachers who adopted a "student-focused approach" used a wider repertoire of teaching methods in comparison to teachers with a "teacher-focused approach" (Coffey \& Gibbs, 2002). After one semester of two- and three-semester long initial PTCs, UK university teachers showed significant improvements in scores measuring learning, enthusiasm, organisation and rapport (Coffey \& Gibbs, 2000); again, the difficulty of distinguishing the effects of training from the effects of experience in teaching must be highlighted. 


\section{The path to quality university teaching}

Pleschová et al. (2012) describe how to best prepare academics for teaching and enhance teaching and learning:

1) Professional educational developers should work with individual teachers; professionals with qualifications in primary and secondary education may not be the right candidates for educational developers. "The expert in academic pedagogy who conduct[s] initial and in-service training should ideally be a university teacher who stands in the lecture hall every day and who interacts with students through the elaboration of their graduation papers. Additionally, he or she needs to have earned an adequate pedagogical qualification with a serious focus on academic pedagogy" (Leitner, 1998, p. 347).

2) Academics must be encouraged to experiment with student-centred curricula and teaching methods; educational developers should transfer information and innovations in teaching across disciplinary boundaries.

3) SET is an important way of ensuring student input into teaching enhancement; educational developers can help with the related interpretation and action planning.

4) Regular evaluation of the impact of educational development programmes and their subsequent restructuring is also essential (Pleschová et al., 2012).

Marentič Požarnik (1998) presents seven models of didactic training of university teachers: i) initial training programmes for assistants with at least one year of teaching experience; ii) mentorship of a novice by an experienced university teacher, not only in research but also in teaching; iii) (mono)thematic seminars and courses of various fields; iv) pedagogical workshops; v) action research projects; vi) network of experts; and vii) peer training. Other areas of great importance include: training for professional educational developers, which should be organised in teaching and learning centres or in human resource units; the establishment of educational development programmes; and the creation of educational development units that offer teacher development programmes (Pleschová et al., 2012). The High Level Group on the Modernisation of HE (2013) recommends, inter alia: the establishment of a European Academy for Teaching and Learning; continuous professionalisation and development of HE teaching staff with mandatory certified training (by 2020, all teachers should have received certified PT); decisions on entrance, progression and habilitation should take into account the assessment of teaching 
competence; and researchers should be given an opportunity to gain professional teaching qualifications. Last but not least, HEIs should encourage "student feed-back which could detect problems in the teaching and learning environment early on and lead to faster, more effective improvement" (ibid., p. 64).

\section{Connection between SET and PT}

The quality of teaching is inseparably linked to the quality of learning: the reputation of a university is to a great extent based on the quality of its graduates. The final goal of academic pedagogy is not to satisfy the teacher, but to satisfy the student as well (Leitner, 1998). "In many countries, universities have introduced SET as a way of introducing student input into teaching enhancement" (Pleschová et al., 2012, p. 17). SET is seen "as a valuable tool to improve teaching and student learning outcomes" (Kogan, Schoenfeld-Tacher \& Hellyer, 2010), assuming that students learn more from good teachers (Cohen, 1981) and that they know best whether the teaching they receive is adequate for them (Clayson \& Haley, 1990 in Kogan, Schoenfeld-Tacher \& Hellyer, 2010).

However, according to various authors (Clayson, 2009; Cohen, 1981; Kogan, Schoenfeld-Tacher \& Hellyer, 2010; Lumsden \& Scott, 1984; Stark \& Freihstat 2014, p. 2; Zabaleta 2007), several studies argue that SET does not actually evaluate teaching. It is an open issue whether the students' or teachers' characteristics are the main factors in determining the students' opinion of a teacher, and whether students opinion of teachers is effected by (higher) grades (Lumsden \& Scott, 1984, p. 648; Stark \& Freihstat, 2014). Cohen (1981, p. 281) adds that "the most critical question about student ratings of instruction is whether /... / they actually measure teaching effectiveness"; if so, there should be a strong positive correlation between students' learning and SET. Due to various external influences, the question of the reliability, validity and usability of student evaluations has been raised, as well as the question of what exactly students evaluate (ibid.). On the other hand, Seldin (1997) claims that SET presents the most common method of gathering evidence on the quality and effectiveness of teaching, study programmes and HEIs in general. Although SET can be a valuable tool for improving teaching and learning outcomes, the collection of data and information alone is not sufficient; evidence on the quality of teaching should also be collected from other sources (Pleschová et al., 2012; Stark \& Freihstat, 2014) and combined with other methods, i.e., teaching portfolios, student interviews for the elimination of anonymity, introduction of students' accountability, class observations, unbiased peer evaluations, self-evaluations, etc. (Zabaleta, 2007). In order to create educational change (Pleschová et al., 
2012, p. 17; Stark \& Freihstat, 2014), teachers need access and opportunities to discuss evaluation results with colleagues, thus enabling them to address weaknesses and build on strengths.

As regards the Slovenian HE system, we agree with Marentič Požarnik (2009) that the introduction of compulsory SET may represent one of the most important developments in recent years in the field of teaching. It is believed that SET has been an important complement to the conditions of assessing pedagogical qualification in the process of habilitation in Slovenia, i.e., mentoring and co-mentoring, the number and quality of master's and doctoral theses, preparation of textbooks and similar materials, initial and sustained PTCs, etc. In the process of the first habilitation, an important role is also attributed to the "probationary lecture". In Article 11 of the national Minimum Standards for the Appointment of HE Teachers, Researchers and Faculty Assistants at HEIs (OG RS, 2010), it is stated that, in every habilitation of teachers or faculty assistants to a higher position or re-habilitation to the position currently held, the candidate must submit an opinion of the student council based on the results of a student survey or other instruments for verifying pedagogical work. The results of SET are obligatory in the process of habilitation at all four Slovenian universities; conversely, in habilitation procedures, only two Slovenian universities require the submission of a certificate of participation in PT programmes. As the survey results described below indicate, university teachers hold different opinions and beliefs regarding the importance of initial and sustained PTCs, regarding SET in the process of habilitation, and regarding the "probationary lecture" as a way of assessing one's pedagogical qualification.

\section{Method}

\section{Data collection instrument and data collection methods}

The data collection of the quantitative empirical research, undertaken in 2013, was based on an online questionnaire using a 5-point Likert scale in five core questions. The initial questionnaire was tested on a sample of 24 university teachers and associates. The questionnaire results were sensibly transformed with the aid of univariate statistics.

\section{Population and sample}

The link to the online questionnaire was sent to 5,650 teachers' e-mail addresses, which had been found on the webpages of all Slovenian HEIs (nearly 
$70 \%$ of the Slovenian HE teaching population). After a second e-invitation, 513 respondents (slightly less than $10 \%$ of all contacted individuals) from all four Slovenian universities and some private HEIs answered the questionnaire. The respondents held various academic titles and belonged to various ISCED groups of work, ${ }^{4}$ thus covering a representative sample of the population. We urge additional caution when interpreting or using the survey data due to the low response rate. However, in accordance with some researchers who claim that data acquired with a lower response rate can still provide accurate measurements (Horta, 2013), we argue that the acquired data still constitutes an overview of the current situation in Slovenia. The data was analysed with SPSS software (version 19), and the analysis was mostly based on comparing the calculated univariate and bivariate statistics, as well as ANOVA analysis and the Chi-square test.

\section{Results}

The respondents answered questions and expressed their opinions regarding university teachers' pedagogical education/qualification, based on statements regarding:

a) initial PTCs, which should be given to all candidates on the first habilitation to the position of university teacher;

b) initial PTCs (on the first habilitation to the position of university teacher), which should be given to all teachers who have no prior pedagogical and/ or adult education;

c) sustained PTCs (every five years) for all university teachers;

d) evidence/certificates of completion of PTCs as a compulsory part of the documentation in the process of habilitation;

e) involvement in sustained PTCs for all university teachers whose SET show poor results;

f) SET as an appropriate tool for assessing the pedagogical qualification of an

4 The International Standard Classification of Education - ISCED 1997 (UNESCO 2012) has 25 fields of education organised within nine broad groups. In the survey, nine groups were merged into six as follows, with the percentages of the respondents being added: 1 ) Education $-10.7 \%$ (14 Teacher Training and Education Science), 2) Humanities and Arts - 15.6\% (21 Arts, 22 Humanities), 3) Social Sciences - 26.1\% (31 Social and Behavioural Science, 32 Journalism and Information, 34 Business and Administration, 38 Law, 81 Personal Services, 84 Transport Services, 86 Security Services), 4) Natural Sciences - 19.3\% (42 Life Sciences, 44 Physical Sciences, 46 Mathematics and Statistics, 48 Computing, 6 Agriculture, 62 Agriculture, Forestry and Fishery, 64 Veterinary, 85 Environmental Protection), 5) Engineering, Manufacturing and Construction $-18.3 \%$ (52 Engineering and Engineering Trades, 54 Manufacturing and Processing, 58 Architecture and Building) and 6) Health and Welfare $-9.9 \%$ ( 72 Health, 76 Social Services). 
individual in the habilitation process;

g) the "probationary lecture" as crucial in assessing the pedagogical qualification of an individual; and

h) the quality of the work of the specially appointed commission at the "probationary lecture" that an individual has to pass in the process of the first habilitation.

The results showed statistically significant differences in the responses to the above statements (see statements: $a-d$ ) regardless of different ISCED groups, academic titles and whether or not the respondents had been involved in PTCs (Table 1). The respondents attributed greater importance to $(b)$ initial PTCs in the case of no prior pedagogical education and less importance to $(a)$ initial training for all university teachers (private HEIs and lectors/language teachers $(\mathrm{N}=12)$ are excluded). At the same time, respondents (with the exception of lectors/language teachers $(\mathrm{N}=12))$ attributed less importance to $(c)$ sustained PTCs every five years than to initial training ( $a$ and $b$ ).

It is interesting that, when taking into account ISCED groups, teachers from Health and Welfare seem to attribute the greatest importance to $(a)$ initial PTCs (4.10) and to (d) the mandatory submission of a certificate on PTCs (3.44). In the case of (a) initial PTCs, a Games-Howell post-hoc test later revealed that Health and Welfare teachers attribute greater importance to initial PTCs than teachers from Humanities and Arts $(\mathrm{p}=0.007)$, as well as Natural Sciences $(p<0.001)$ and Engineering $(p=0.036)$ teachers. For the mandatory submission of a certificate on PTCs (d), a Gabriel post-hoc test showed that again Health and Welfare teachers attribute greater importance to certificates than teachers from the Humanities and Arts $(\mathrm{p}=0.042)$ and the Natural Sciences $(p=0.006)$ groups. At the same time, many of the respondents from the Health and Welfare group had been involved in PTCs. ${ }^{5}$ Teachers from the Education group (who were likely to have finished a pedagogical study programme for teaching at the primary and/or secondary level of education) are most likely to consider initial PTCs as obligatory only for university teachers who have no prior formal pedagogical education. However, formal education for teaching in primary and secondary schools cannot be considered as sufficient for teaching in HE. The respondents with higher titles (full professors, associate professors, assistant professors, as well as assistants) seem to attribute the lowest importance to statements $a, c$ and $d$, with sustained PTCs every five years $(c)$

5 The respondents' participation in PTCs, according to ISCED groups (percentage and mean): total $(31.4 \%, 37.4)$; Education $(21.8 \%, 53.8)$; Humanities and Arts $(26.3 \%, 42.1)$; Social Sciences $(40.3 \%$, 42.1); Natural Sciences (21.2\%, 40.7); Engineering, Manufacturing, Construction (20.2\%, 28.1); Health and Welfare $(66.7 \%, 24.6)$. 
standing out in particular. Post-hoc tests later revealed that those four groups of respondents attribute significantly less importance to $a$ and $c$ courses than Higher Lecturers and Lecturers, as well as Lectors ( $\mathrm{p}$ values lower than 0.05).

Table 1. University teachers opinions on PTCs.

\begin{tabular}{|c|c|c|c|c|c|}
\hline & & a & b & c & d \\
\hline & Total & 3.70 & 4.01 & 3.14 & 3.19 \\
\hline \multirow{6}{*}{ 포 } & UL & 3.74 & 4.08 & 3.13 & 3.14 \\
\hline & UM & 3.48 & 3.87 & 3.09 & 3.04 \\
\hline & UPR & 3.76 & 4.17 & 2.95 & 3.43 \\
\hline & UNG & 3.44 & 3.94 & 2.94 & 3.38 \\
\hline & Private HEls & 3.90 & 3.89 & 3.40 & 3.44 \\
\hline & Significance of mean differences (HEI) & 0.085 & 0.307 & 0.262 & 0.107 \\
\hline \multirow{7}{*}{ 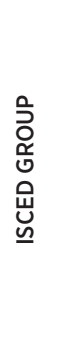 } & Education & 3.89 & 4.44 & 3.40 & 3.45 \\
\hline & Humanities and Arts & 3.45 & 4.00 & 2.99 & 2.95 \\
\hline & Social Sciences & 3.93 & 4.04 & 3.47 & 3.38 \\
\hline & Natural Sciences & 3.36 & 3.84 & 2.61 & 2.87 \\
\hline & Engineering, Manufacturing and Construction & 3.63 & 3.74 & 3.05 & 3.11 \\
\hline & Health and Welfare & 4.10 & 4.33 & 3.43 & 3.57 \\
\hline & Significance of mean differences (ISCED groups) & $<0.001$ & 0.001 & $<0.001$ & $<0.001$ \\
\hline \multirow{9}{*}{ 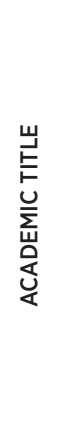 } & Full Professor & 3.39 & 3.80 & 2.97 & 3.18 \\
\hline & Associate Professor & 3.74 & 4.01 & 2.92 & 3.05 \\
\hline & Assistant Professor & 3.56 & 3.94 & 2.96 & 2.96 \\
\hline & Higher Lecturer & 4.14 & 4.18 & 3.66 & 3.59 \\
\hline & Lecturer & 4.28 & 4.39 & 3.72 & 3.81 \\
\hline & Lector (language teacher) $(\mathrm{N}=12)$ & 4.58 & 4.42 & 4.42 & 3.75 \\
\hline & Assistant & 3.61 & 4.01 & 3.13 & 3.19 \\
\hline & Instructor $(\mathrm{N}=2)$ & 4.00 & 5.00 & 3.50 & 4.50 \\
\hline & Significance of mean differences (Academic titles) & $<0.001$ & 0.085 & $<0.001$ & $<0.001$ \\
\hline \multirow{3}{*}{  } & Participation in PT & 3.48 & 3.91 & 2.94 & 2.99 \\
\hline & No participation & 4.18 & 4.24 & 3.58 & 3.64 \\
\hline & Significance of mean differences (participation) & $<0.001$ & $<0.001$ & $<0.001$ & $<0.001$ \\
\hline
\end{tabular}

The ANOVA model is statistically significant at the level of 0.05 (if p value is lower than 0.05 )

LEGEND: a) initial PTCS for all teachers; b) initial PTCS for teachers with no prior pedagogical education; c) sustained PTCs for all teachers; d) certificates of PTCs as a compulsory part of the habilitation process 
According to Table 1, the respondents who had been involved in PTCs attributed less importance to initial $(a, b)$ and sustained PTCs $(c)$, as well as to a certificate of participation in PTCs $(d)$ in comparison to respondents who had not been involved in PTCs $(\mathrm{p}<0.05)$. This may point to the findings of Postareff, Lindblom-Ylänne and Nevgi (2007), who found that shorter courses (fewer than 30 ECTS) may make teachers more uncertain about their teaching skills. Our study shows that respondents had participated in PTCs for an average of only 37.4 hours (footnote 3 ), which we regard as limited participation, considering that one ECTS represents 25-30 hours of candidate workload.

In this context, we verified whether the respondents' opinions vary depending on the duration of their PT. Due to the short duration of the courses, we were unable to verify the differences in their opinions on extensive participation in PT, such as a one-year training programme (ibid.). Consequently, in calculating differences in our research, the limit was established at 50 hours, whereby the first group of respondents consisted of participants included in PTCs of up to 50 hours and the second group of participants in PTCs of 51 hours or more (Table 2). The respondents of the second group (23.6\% of the respondents involved in PT) were more in favour of PTCs: the t-test results showed that there are statistically significant differences between these two groups in the case of initial PTCs for all university teachers $(a)$ and in the case of mandatory submission of certificates of training $(d)$. This could indicate that teachers with greater participation in PTCs have already gained greater confidence in their teaching abilities and in PTCs as such. However, this result could also be explained by teachers' (prior) interest in pedagogical issues in general, and not the length of their participation in PTCs.

Table 2. University teachers' opinions on the importance of PTCs according to the extent of their participation in courses.

\begin{tabular}{lcccc}
\cline { 2 - 5 } & a & b & c & d \\
\hline Total & & & & \\
\hline 1-50 hours of PTCs & 4.08 & 4.18 & 3.52 & 3.55 \\
51 and more hours of PTCs & 4.59 & 4.47 & 3.81 & 4.00 \\
\hline Significance of mean differences (institutions) & 0.003 & 0.151 & 0.184 & 0.037 \\
\hline
\end{tabular}

The differences are statistically significant at the level of 0.05 (if $p$ value is lower than 0.05 ).

LEGEND: a) initial PTCS for all teachers; b) initial PTCs for teachers with no prior pedagogical education; c) sustained PTCs for all teachers; d) certificates of PTCs as a compulsory part of the habilitation process 
Given that SET should not be used for teachers' career decisions, because, according to the aforementioned authors, it does not evaluate (only) teaching, we further considered the respondents' opinion (Table 3) on: e) involvement in sustained PTCs of all university teachers whose SET shows poor results, and f) SET as an appropriate tool for assessing the pedagogical qualification of an individual in the habilitation process. The ANOVA revealed that there are statistically significant differences in the case of respondents with or without participation in PTCs, whereby those without participation in PT are more convinced that university teachers should be involved in sustained PT in the case of poor results in SET.

Table 3. University teachers' opinions on SET in the context of PTCs and the process of habilitation.

\begin{tabular}{lcc}
\cline { 2 - 3 } & $\mathrm{e}$ & $\mathbf{f}$ \\
\hline Participation in PTCs & 3.76 & 2.83 \\
No participation & 4.09 & 2.81 \\
\hline Significance of mean differences (participation) & $<0.001$ & 0.831 \\
\hline
\end{tabular}

The differences are statistically significant at the level of 0.05 (if $p$ value is lower than 0.05 ).

LEGEND: e) all teachers whose SET show poor results involved in sustained PTCS; f) SET as an appropriate tool for assessing pedagogical qualification

Since, in Slovenia, the pedagogical qualification of university teachers is (often) assessed through a "probationary lecture", we were also interested in the respondents' opinions (Table 4) on: $g$ ) the "probationary lecture", which is a condition for the first habilitation, as crucial in assessing the pedagogical qualification of the individual, and $h$ ) the quality of the work of the members of the specially appointed commission at the "probationary lecture" that the individual passed in the process of the first habilitation. In the case of statement $(g)$, all of the respondents were included in the analysis $(\mathrm{N}=513)$, while, in the case of statement $(f)$, only data of teachers who themselves gave a "probationary lecture" $(\mathrm{N}=407)$ were analysed. 
Table 4. Teachers' opinions on the "probationary lecture".

\begin{tabular}{lcc} 
& & \\
\cline { 2 - 3 } & $\mathbf{g}$ & $\mathbf{h}$ \\
\hline Total & 3.25 & 4.01 \\
\hline UL & 3.23 & 3.93 \\
UM & 3.05 & 3.84 \\
UPR & 3.21 & 4.03 \\
UNG & 3.44 & 3.93 \\
Private HEls & 3.63 & 4.34 \\
\hline Significance of mean differences (HEIs) & 0.026 & 0.04 \\
\hline Education & 3.16 & 4.15 \\
Humanities and Arts & 3.40 & 3.87 \\
Social Sciences & 3.22 & 3.96 \\
Natural Sciences & 3.21 & 4.00 \\
Engineering, Manufacturing and Construction & 3.16 & 3.97 \\
Health and Welfare & 3.43 & 4.11 \\
\hline Significance of mean differences (ISCED groups) & 0.615 & 0.544 \\
\hline Full Professor & 3.49 & 4.01 \\
Associate Professor & 3.01 & 3.83 \\
Assistant Professor & 3.29 & 4.04 \\
Higher Lecturer & 3.34 & 3.93 \\
Lecturer & 3.50 & 4.17 \\
Lector (language teacher) (N=12) & 3.58 & 3.67 \\
Assistant & 3.03 & 4.20 \\
\hline Instructor (N=2) & 0.286 \\
\hline
\end{tabular}

The ANOVA model is statistically significant at the level of 0.05 (if $p$ value is lower than 0.05 ).

LEGEND: g) the "probationary lecture" as crucial in assessing one's pedagogical qualification; $h$ ) quality of the work of the specially appointed commission at the "probationary lecture".

Table 4 shows statistically significant differences in the importance that respondents attributed to the "probationary lecture". In the case of private HEIs, the respondents' opinions on the importance of the "probationary lecture" seem to be the highest (3.63), and they also attributed the highest value to the quality of the commission's work (4.34). A post-hoc test revealed that the perceptions of teachers from private HEIs were statistically different from those of teachers from the largest Slovenian universities, UL and UM ( $p$ values lower than 0.05), but not from those of teachers from the other two universities (UNG and UPR). It should be stressed, however, that more than $48 \%$ of the 
respondents from private HEIs work in the Health group. In comparison to the other ISCED groups, the respondents from Health and Welfare attributed the most importance to the "probationary lecture". The results also revealed that a total of $2.0 \%$ of the teachers had never given a "probationary lecture", even though it is obligatory by law. ${ }^{6}$ Taking into account the fact that the completion of a PTC is not a prerequisite for habilitation to a university teaching position, this result is undoubtedly worrying, as it raises the question of the individual's pedagogical qualification: only $31.4 \%$ of the respondents had completed a PTC (footnote 3 ), a percentage that is nonetheless surprisingly high. In this context, one shortcoming of our survey should be pointed out, i.e., data on the respondent's own acquisition of knowledge was not collected.

\section{Conclusion and discussion}

Pedagogical qualification of university teachers is often taken for granted in academic culture. Why would someone require professionalisation if he or she is already a professional? Academic culture includes specific rules of behaviour and conduct of members of the academic community, which is maintained and transmitted to younger academic generations (Kump, 1994, p. 23). However, the preservation of old habits, such as those in the field of pedagogical skills and competences, should not be (strictly) maintained under the influence of modern changes. Whereas, in the past, university teachers used to teach a handful of talented students who most likely had quite similar interests to the teachers themselves (Marentič Požarnik 2009, p. 342) and possessed a deep approach to learning, nowadays the majority of students have a superficial approach to learning and only achieve a deep approach in the case of the best conditions for teaching and learning (Biggs, 1999, p. 58). The fact is that we are failing to affect the quality of input (i.e., students who massively enter HE). If graduates are to achieve at least the minimal academic level, and if an appropriate level of student knowledge, skills and competences is be maintained, "something" should or must be done during study in order to achieve the highest possible quality of the output (i.e., graduates). Barnett (1992) states that, from the perspective of students, research is quite irrelevant; on the other hand, quality teaching with high-quality, modern and appropriate methods and approaches to pedagogical work can lead to quality students and graduates. In the eyes of the students, the undergraduate level should place greater emphasis on

6 Upon their first habilitation, assistants and instructors do not need to demonstrate pedagogical qualification (OG RS 2010); nonetheless, 9.4\% of assistants had already given a lecture, which could be a result of being reappointed to the same position. 
teaching rather than research, which is why an important role could be given to quality PT of university teachers, and to the assessment of their pedagogical qualification, using the "probationary lecture", SET, portfolios, peer-review systems, etc. However, SET represents feedback on teachers' work post festum, while PTCs offer the possibility of improvement in advance.

Professional PT is still not considered a requirement for entry to a teaching career in Slovenian (or European) HE: almost $70 \%$ of the respondents in our survey had never participated in such training. The respondents attributed less importance to (a) initial PTCs for all university teachers (Table 1: total 3.70) in comparison to (b) PT intended only for those without prior formal education for teaching at primary or secondary level (Table 1: total 4.01). It is not surprising that those who have graduated from a pedagogical study programme are (wrongly) regarded as fully qualified for teaching in $\mathrm{HE}$, as pointed out by Pleschová et al. (2012). Furthermore, teachers with the highest academic titles (full professors, associate professors and assistant professors, as well as assistants) attribute significantly less importance to (a) initial PTCs for all teachers and (c) sustained PTCs for all teachers. It is assumed that respondents with higher academic titles feel adequately pedagogically qualified (primarily) due to their long teaching experience. At this point, it would be reasonable to further verify teachers' approaches to teaching and students' approaches to learning according to Coffey and Gibbs (2000, 2002) and Trigwell, Prosser and Waterhouse (1999). Pleschová et al. (2012) also point to the problem of perpetuating old teaching methods: younger teachers often follow and imitate their senior and more experienced colleagues in their teaching practices. The question is whether more experienced teachers' pedagogical approaches are still adequate, and whether these teachers respond to the needs of contemporary massive HE with an extremely heterogeneous population of students.

However, respondents from the Health and Welfare group in the present research positively stand out with their responses in terms of both initial and sustained PT, as well as with their opinion on the relevance of documents and certificates in habilitation procedures. At the same time, the results showed that these respondents had been involved in PTCs to the greatest extent (66.7\%), although their PT had been shorter on average (24.6 hours) and they had mainly participated in informal courses of short duration, largely provided at private HEIs. Despite the short duration of their PT, the respondents' awareness of the importance of acquiring pedagogical knowledge for teaching in $\mathrm{HE}$ may have risen. As Postareff, Lindblom-Ylänne and Nevgi (2007) found, only positive effects of PTCs on teaching were mentioned by teachers; however, the authors also emphasised that a training process of a long duration results in 
more positive effects on teachers' pedagogical thinking and their conceptions of teaching and learning (ibid.). Although our survey cannot be placed in the context of their findings, as our respondents had been involved in PTCs of insufficient duration - only 14 participants had attended PT of more than 100 hours (8.7\% of those who had participated in PTCs), which amounts to approximately 5 ECTS - in our research, the group with more hours of PT (51 hours or more) preferred PTCs and the importance of proving one's participation in PTCs for habilitation procedures.

Our study showed that (only) 31.4\% of the respondents in Slovenia had been involved in different PTCs, which seems adequate according to Marentič Požarnik (2009), who found that approximately $5 \%$ of eligible staff had attended formal PTCs at the Centre for Educational Development at the Faculty of Arts, UL. It must be emphasised that, in our study, the term PTC includes various forms of HE training courses, i.e., rhetoric, teamwork, didactic, e-learning for university teachers, etc., as well as being connected with SET. Based on the existing practice and its unclear definition in the national Minimum Standards, as well as in institutional criteria, poor participation in PTCs was expected in our research. We therefore verified the share of respondents who had passed the "probationary lecture" as the most important evidence of the pedagogical qualification of new teachers according to minimum standards and institutional criteria. We found that $2 \%$ of all respondents had not given a "probationary lecture", even though it is a condition for habilitation according to legal provisions (in this context, the question of internal and external evaluation and control is also relevant). Furthermore, we verified the level of importance respondents attribute to the "probationary lecture", in terms of assessing one's pedagogical qualification. The "probationary lecture" as crucial for assessing pedagogical qualification was scored by the respondents at 3.25 on a 5 -point Likert scale. The quality of the commission's work in the "probationary lecture" also scored highly (4.01), which is definitely a positive finding, as anecdotal evidence has often emerged on the unsystematic and unprofessional work of the commission. We believe that the quality implementation of the "probationary lecture" is crucial for the assessment of pedagogical qualification; however, it cannot and should not be the only tool for assessing university teachers' pedagogical qualification. A combination of initial PTCs followed by the "probationary lecture" (or vice versa) could lead to better qualification for university teaching. In addition, higher quality of teaching could be achieved with sustained PTCs combined with other methods.

In the process of habilitation, all Slovenian universities, on the basis of their own institutional criteria, take account of SET, which, according to 
Marentič Požarnik (2009), represents important progress in university teaching in Slovenia. Consequently, we were interested in the level of importance attributed to SET by university teachers. A statistically significant majority of the respondents who had not been involved in PTCs, or who had been involved in courses of very short duration, consider that (only) university teachers whose SET shows poor results should be involved in sustained PT. Again, the emphasis of SET as the (only) reason for participation in PTCs could be the consequence of these respondents' nonparticipation - or brief participation (on average 37.4 hours) - in PT, which, according to Postareff, Lindblom-Ylänne and Nevgi (2007), may make teachers more uncertain about their teaching skills, and consequently can also affect their opinion on the effectiveness of PT. However, all of the respondents - those who had and had not participated in PTCs - attributed slightly more than 2.8 points on a 5-point Likert scale to SET as an appropriate tool for assessing the pedagogical qualification in habilitation procedures. This undoubtedly indicates that teachers are aware of the external factors that impact students' opinion on the quality of teaching, as is also stressed by Cohen (1981).

With respect to the existing practice and the adopted minimum standards and institutional criteria in Slovenia, which explicitly require only the "probationary lecture" and SET in habilitation procedures, it should be stressed that the respondents do not attribute great importance to the latter two obligations in comparison to various kinds of PTCs. In accordance with this research, we recommend a well-balanced combination of various methods and factors in habilitation procedures in Slovenian HE: in addition to the "probationary lecture" and SET, it would be reasonable to at least introduce various optional PTCs for university teachers, as well as other optional measures, such as teaching portfolios, student interviews for the elimination of anonymity, class observations, unbiased peer evaluations, etc. However, teachers' inclusion in various courses and other methods of pedagogical development should be properly considered and rewarded in habilitation procedures. In this context, a comprehensive consideration and renewal of the habilitation system in Slovenia would be reasonable.

\section{References}

Aškerc, K. (2013). Didaktično usposabljanje visokošolskih učiteljev in sodelavcev z vidika razvoja človeških virov v visokem šolstvu [Pedagogical Training of Higher Education Teaching Staff in Terms of Human Resource Development in Higher Education] (Master Thesis). Maribor: Univerza v Mariboru: Ekonomsko-poslovna fakulteta. 
Barnett, R. (1992). Linking Teaching and Research: A Critical Inquiry. The Journal of Higher

Education, 63(6), 619-636.

Biggs, J. (1999b). What the Student Does: teaching for enhanced learning. Higher Education Research \& Development, 18(1), 57-75.

Clayson, D. E. (2009). Student Evaluations of Teaching: Are They Related to What Students Learn?:

A Meta-Analysis and Review of the Literature. Journal of Marketing Education, 31(1), 16-30.

Cohen, P. A. (1981). Student Ratings of Instruction and Student Achievement: A Meta-analysis of

Multisection Validity Studies. Review of Educational Research, 51(3), 281-309.

Coffey, M., \& Gibbs, G. (2000). Can Academics Benefit from Training? Some Preliminary Evidence. Teaching in Higher Education, 5(3), 385-389.

Coffey, M., \& Gibbs, G. (2002). Measuring Teachers' Repertoire of Teaching Methods. Assessment \& Evaluation in Higher Education, 27(4), 383-39o.

Faculty of Arts, University of Ljubljana (FF UL). 2013. Osnove visokošolske didaktike - razpis za vpis v program. Retrieved 10. 9. 2014 from http://www.ff.uni-lj.si/Portals/o/Dokumenti/CPI/ ProgramiZaIzpopolnjevanje/OVD_predstavitev_programa.pdf.

Fry, H. (2006). Professional Development for Teaching in Higher Education: A Brief Account of the Evolution of Accredited Programmes in the UK. Zeitschrift für Hochschulentwicklung, 1(2), 95-108. Gibbs, G., \& Coffey, M. (2004). The impact of training of university teachers on their teaching skills, their approach to teaching and the approach to learning of their students. Active Learning in Higher Education, 5(1), 87-100.

High Level Group on the Modernisation of Higher Education (2013). Report to the European Commission on Improving the Quality of Teaching and Learning in Europe's Higher Education Institutions. Retrieved 10. 9. 2014 from http://ec.europa.eu/education/library/reports/modernisation_ en.pdf.

Horta, H. (2013). Deepening our Understanding of Academic Inbreeding Effects on Research Information Exchange and Scientific Output: New Insights for Academic Based Research. Higher Education, 65(4), 487-510.

Kogan, L. R., Schoenfeld-Tacher, R., \& Hellyer, P. W. (2010). Student evaluations of teaching: perceptions of faculty based on gender, position and rank. Teaching in Higher Education, 15(6), $623-636$.

Kump, S. (1994). Akademska kultura [Academic Culture]. Ljubljana: Znanstveno in publicistično središče.

Leitner, E. (1998). The Pedagogical Qualification on the Academic Teaching Staff and the Quality of Teaching and Learning. Higher Education in Europe, XXIII(3), 339-349.

Lisewski, B. (2006). The professional development of new higher education teachers from communities of practice perspective: the challenge of 'accounting for change' in 'situated pedagogy'.

In Third Education in a Changing Environment Conference. UK: University of Salford. Lumsden, K., \& Scott, A. (1984). How to maximize golden opinions. Applied Economics, 16(5), $647-654$ 
Marentič Požarnik, B. (1998). Izpopolnjevanje univerzitetnih učiteljev za boljše poučevanje kot del kulture kakovosti [Supplemental Training of University Teachers for Better Teaching as Part of Quality Culture]. In B. Mihevc, \& B. Marentič Požarnik (Eds.), Za boljšo kakovost študija: Pogovori o visokošolski didaktiki [For Better Quality of Study: Discourse on Higher education Didactics] (pp. 29-48). Ljubljana: Center za pedagoško izobraževanje Filozofske fakultete, Slovensko društvo za visokošolsko didaktiko.

Marentič Požarnik, B. (2009). Improving the quality of teaching and learning in higher education through supporting professional development of teaching staff. Napredak, 150(3-4), 341-359.

Norton, L., Richardson, J. T. E., Hartley, J., Newstead, S., \& Mayes, J. (2005). Teachers' beliefs and intentions concerning teaching in higher education. Higher Education, 50(4), 537-571.

Uradni list Republike Slovenije (Ur. 1.). 2010. Minimalni standardi za izvolitev $v$ nazive visokošolskih učiteljev, znanstvenih delavcev in visokošolskih sodelavcev na visokošolskih zavodih [Official Gazette of the Republic of Slovenia (OG RS). 2010. Minimum Standards for the Appointment of Higher Education Teachers, Researchers and Faculty Assistants at Higher Education Institutions]. No. 95/10, 17/11. Retrieved 05. 05. 2013 from http://www.pisrs.si/Pis. web/pregledPredpisa?id=DRUG3538.

Uradni list Republike Slovenije (Ur. 1.). 2011. Resolucija o Nacionalnem programu visokega šolstva 2011-2020 [Resolution on National Higher Education Programme 2011-2020]. Uradni list No. 41/2011. Retrieved 11. 10. 2014 from http://www.pisrs.si/Pis.web/pregledPredpisa?id=DRUG3538. Pleschová, G., Simon, E., Quinlan, K. M., Murphy, J., Roxa, T., Szabó, M., with comments from Clement, M., \& Buelens, H. (2012). The Professionalisation of Academics as Teachers in Higher Education. France: European Science.

Postareff, L., Lindblom-Ylänne, S., \& Nevgi, A. (2007). The effect of pedagogical training on teaching in higher education. Teaching and Teacher Education, 23(2007), 557- 571.

Rosado Pinto, P. (2008). Teacher Training in Higher Education: the Case of Teachers of Medicine. Educational Sciences Journal 7 (Sep-Dec), 107-120.

Seldin, P. (1997). The Teaching Portfolio: A Practical Guide to Improved Performance and Promotion/ Tenure Decisions (Sec. Ed.). Bolton, MA: Anker Publishing Company.

Stark, P. B., \& Freishtat, R. (2014). An evaluation of course evaluations. Science Open ResearchSection: SOR-EDU. Retrieved 19. 10. 2015 from http://www.physics.emory.edu/faculty/weeks/journal/ stark-preprint14.pdf.

Trigwell, K., Prosser, M., \& Waterhouse, F. (1999). Relations between teachers' approaches to teaching and students' approaches to learning. Higher education $37(1), 57-70$.

United Nations Educational, Scientific and Cultural Organization (UNESCO) (2012). International Standard Classification of Education ISCED 2011. Retrieved 05. 04.2014 from http://www.uis.unesco. org/Education/Documents/isced-2011-en.pdf. University of Ljubljana (UL). 2012. Criteria for Appointment to the Titles of University Teacher, Researcher and Associate at the University of Ljubljana. Retrieved 18. 10. 2013 from http://www.uni-lj. si/university/organization_legal_framework_and_reports/statutes_of_ul_and_regulations/. 
University of Ljubljana (UL). 2013. Quality - University of Ljubljana, 2012-2015. Retrieved 12. 04. 2016 from http://www.uni-lj.si/o_univerzi_v_ljubljani/kakovost/projekt_kul.

University of Maribor (UM). 2012. Criteria for the appointment of faculty ranks for university teachers and other employees in higher education. Retrieved 18. 10. 2013 from http://www.um.si/en/research/ habilitation/Pages/default.aspx.

University of Nova Gorica (UNG). 2013. Regulations for the determination of conditions and appointment procedures for research and teaching positions at the University of Nova Gorica. Retrieved 18. 10. 2013 from https://www.ung.si/org/img/storage/pravilniki-obrazci/pravila_habilitacije_en.pdf. University of Primorska (UP). 2014a. Merila za izvolitve v nazive Univerze na Primorskem [Criteria for the Appointment to Positions at University of Primorska]. Retrieved 03. 05. 2014 from http:// www.upr.si/index.php?page $=$ ac_content $\&$ item $=90$.

University of Primorska (UP). 2014b. Pregled dela in točkovalnik. Retrieved 03. 05. 2014 from http:// www.upr.si/index.php?page $=$ ac_content $\&$ item $=90$.

University of Primorska (UP). 2014c. Navodila za izvajanje Meril za izvolitve v nazive UP [Guidance on the Implementation of Criteria for the Appointment to Positions at University of Primorska]. http://www.upr.si/index.php?page=ac_content\&item $=90$.

Zabaleta, F. (2007). The use and misuse of student evaluations of teaching. Teaching in Higher Education, 12(1), 55-76.

\section{Biographical note}

Katarina Aškerc Veniger works at Slovenian Centre for Mobility and European Educational and Training Programmes, prior to her current role she worked at the Slovenian Quality Assurance Agency. Her field of research and work include conceptions of university teaching and learning, pedagogical training courses for university teachers, internationalisation of the curriculum and internationalisation at home in higher education etc. She is a doctoral student of the Educational Science - Educational Policies at University of Ljubljana. 